\title{
Effects of the Dictogloss Method in Teaching Listening Skills to Students
}

\author{
Muhaiminah Akib ${ }^{1}$, Dian Saputra² \\ ${ }^{1,2}$ Universitas Muhammadiyah Sorong \\ Email: mina.akib@gmail.com, dian.ums14@gmail.com
}

\begin{abstract}
The purpose of this study was to investigate the effect of the dictogloss method in teaching listening to students' listening skills. This research was designed as a quasi-experimental. This study aims to investigate whether a material or treatment yields a different outcome for participants. There are two classes in this study, namely the experimental class (which is a sample to be treated with the dictogloss method) and the control class (using a method other than dictogloss). The results of this study are the results of data analysis showing that the results of learning skills in listening to the experimental group obtained the average value for the initial test of 60.33 and 71 for the final test score. While the control group using conventional methods has a mean value for the initial test of 60.1 and 70 for the final test. $T$ test results also indicate that the significance value is 0,000 . The significance value states smaller 0.05 , it can be stated that $\mathrm{Ha}$ is accepted and Ho is rejected, which means that there is an influence of the dictogloss method in improving listening skills in students.
\end{abstract}

Keyword: Listening Skill; dictogloss.

\section{BACKGROUND}

More than forty-five percent of communication time is spent listening, which clearly shows how important this skill is in overall language skills (Feyten, 1991)(Ahmadi, Seyedeh, 2016). Listening becomes crucial in the development of human language. Language is predominantly obtained from the acquisition of inputs that can be understood. Listening is also a medium for humans to obtain information as knowledge (Gilakjani and Sabouri, 2016)(Gilakjani and Ahmadi, 2011).

Listening is one of the English skills that students must master. In observations made by researchers in class X students of SMA Muhammadiyah Kota Sorong, it was found that students still found problems listening in English, this was due to the lack of English vocabulary, difficulty identifying goals, main ideas and specific information from listening material. Therefore, the right method is needed to teach listening skills that can help students overcome these problems.

The role of the teacher will be crucial in the implementation of teaching in the classroom (Akib, Abdurrahman and Hamid, 2018). Choosing the right method is expected to be able to overcome this problem. One of the interesting methods in teaching listening is the dictogloss 
method. This method is considered effective because it explains how to teach listening classes based on the dictogloss approach, which offers a bridge between different language skills and promotes collaborative learning in the classroom (Vasiljevic, 2010). In addition, the dictogloss method can improve students' listening abilities (Dista, 2017)(Asrobi and Amni, 2017)(Rahmi, 2016). Dictogloss is a class dictation activity where students listen to a section, record key words and then work together to make a reconstructed version of the text. Initially introduced by Ruth Wajnryb as an alternative method of teaching grammar (Ruth Wajnryb, 1990).

\section{Dictogloss Method}

The original Digtogloss procedure consists of four basic steps: (1) warm-up / preparation in which students learn about the topic and do some preparatory vocabulary, (2) Dictation, when students listen to the text read at normal speed by the teacher and take fragment notes. (3) Reconstruction when learners work together in small groups to reconstruct the version of the text based on their source / notes, (4) Analysis and correction, when students analyze and compare their text with the reconstruction of other students and the original text and make the necessary corrections (Ruth Wajnryb, 1990).

\section{METHOD}

This research was designed as a quasi-experimental. This study aims to investigate whether a material or treatment yields a different outcome for participants.

Table 1. Quasi-experimental design

\begin{tabular}{cccc}
\hline Group & Pretest & Treatment & Posttest \\
\hline Sampel G1 (15 orang) & $\mathrm{T}_{1} \mathrm{E}$ & $\mathrm{X}$ & $\mathrm{T}_{2} \mathrm{E}$ \\
\hline Sampel G2 (18 orang) & $\mathrm{T}_{1} \mathrm{C}$ & - & $\mathrm{T}_{2} \mathrm{C}$ \\
\hline
\end{tabular}




\section{RESULT}

Result of pre-test and post-test

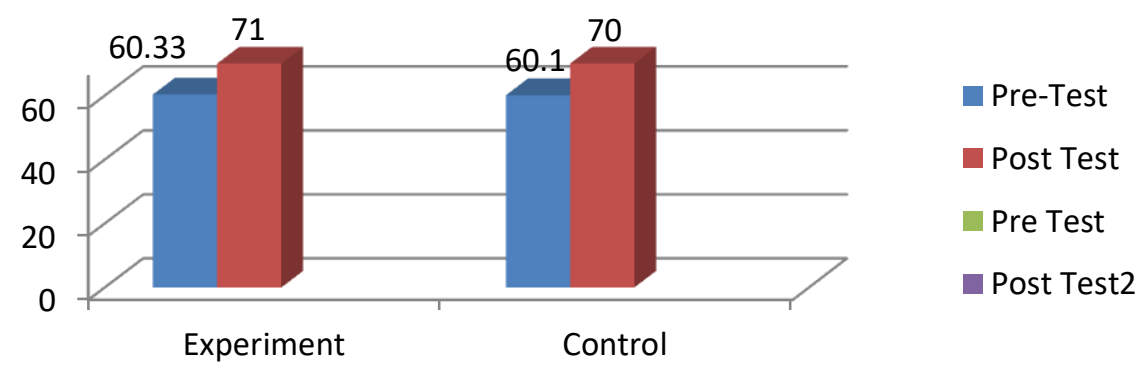

Chart 1 Result of pre—-test and post-test

Based on the results of data analysis shows that the results of learning skills listening in the experimental group obtained the average value for the initial test of 60.33 and 71 for the final test score. While the control group using conventional methods has a mean value for the initial test of 60.1 and 70 for the final test.

Normality Test

Table 2 Tests of Normality

\begin{tabular}{llrrrrrr}
\hline & Kelas & \multicolumn{3}{c}{ Kolmogorov-Smirnov $^{\mathrm{a}}$} & \multicolumn{4}{c}{ Shapiro-Wilk } \\
& & Statistic & df & \multicolumn{1}{c}{ Sig. } & \multicolumn{1}{c}{ Statistic } & \multicolumn{1}{c}{ df } & \multicolumn{1}{c}{ Sig. } \\
\hline & $\begin{array}{l}\text { Pre-test outcomes of } \\
\text { Experiment Class }\end{array}$ &, 173 & 15 &, $200^{*}$ &, 917 & 15 &, 172 \\
$\begin{array}{l}\text { Student } \\
\text { learning } \\
\text { outcomes }\end{array}$ & $\begin{array}{l}\text { Post-test outcomes of } \\
\text { Experiment Class }\end{array}$ &, 187 & 15 &, 169 &, 915 & 15 &, 163 \\
& $\begin{array}{l}\text { Pre-test outcomes of } \\
\text { Control Class }\end{array}$ &, 146 & 18 &, $200^{*}$ &, 924 & 18 &, 155 \\
& $\begin{array}{l}\text { Post-test outcomes of } \\
\text { Control Class }\end{array}$ &, 167 & 18 &, $200^{*}$ &, 932 & 18 &, 209 \\
\hline
\end{tabular}

*. This is a lower bound of the true significance.

a. Lilliefors Significance Correction

Based on the Normality table, it can be seen that the pre-test of the experimental group has a significance level of 0.172 or more than 0.05 , it can be stated that the data is normally distributed. For the post-test distribution of the experimental group having a significance value of 0.163 or more than 0.05 , the post-test data can be said to be normally distributed. For the pre-test data of the control group having a significance value of 0.155 or more than 0.05 , it can be said that the data is normally distributed. Distribution of post-test data of the control group had a significance value of 0.209 or greater than 0.05 , it can be said that the data was normally distributed. From the results of the normality test it can be concluded that the data obtained are normally distributed. 
Homogeneity Test

Table 3. Test of Homogeneity of Variance

\begin{tabular}{llrrrr}
\hline & & Levene Statistic & df1 & df2 & \multicolumn{1}{c}{ Sig. } \\
\hline \multirow{3}{*}{$\begin{array}{l}\text { Student learning } \\
\text { outcomes }\end{array}$} & Based on Mean &, 148 & 3 & 62 &, 930 \\
& Based on Median &, 084 & 3 & 62 &, 969 \\
& Based on Median and with &, 084 & 3 & 61,348 &, 969 \\
& adjusted df &, 047 & & & \\
& Based on trimmed mean &, 157 & 3 & 62 &, 925 \\
\hline
\end{tabular}

Based on the table above it is known that the Significance (Sig) Based on Mean value is $0.930>0.05$, so it can be concluded that the group variance is the same or homogeneous.

T- test

Table 4. Paired Samples Correlations

\begin{tabular}{rrrrr}
\hline & & N & Correlation & \multicolumn{1}{c}{ Sig. } \\
\hline Pair 1 & Pre Test \& Post Test & 15 &, 884 &, 000 \\
\hline
\end{tabular}

Hypothesis:

$\mathrm{HO}$ : There is no influence of the dictogloss method in improving listening skills in students.

H1: There is an influence of the dictogloss method in improving listening skills in students.

The resulting significance value is 0,000 . The significance value states smaller 0.05 , it can be stated that $\mathrm{Ha}$ is accepted and Ho is rejected, which means that there is an influence of the dictogloss method in improving listening skills in students.

After being treated with the dictogloss method, the experimental class showed improved results in post-test scores. This is in accordance with several previous studies (Dista, 2017)(Asrobi and Amni, 2017)(Rahmi, 2016) that the dictogloss method is effective in increasing students' listening ability even though the increase is not too significant.

In addition, the experimental class not only showed improvement in terms of post-test scores, but also students in the experimental class also showed good cooperation in the listening learning process. This is in accordance with Vasiljevic (2010) which states that learning using the dictogloss method also promotes collaborative learning in the classroom (Vasiljevic, 2010). 


\section{CONCLUSION}

Based on the research results it can be concluded that the use of the dictogloss method in learning has a positive influence on listening skills in SMA Muhammadiyah Al-Amin Kota Sorong. This is indicated by the results of hypothesis testing which shows that the significance value obtained is 0,000 less than the significance level of 0.05 . In addition, it can also be seen from the average post-test results, namely the use of the dictogloss method in the experimental class by 71 , while with the use of conventional methods by 70 .

\section{REFERENCE}

Ahmadi, Seyedeh, M. (2016) 'The Importance of Listening Comprehension in Language Learning', International Journal of Research in English Education, 1(1), pp. 7-10. Available at: http://ijreeonline.com/browse.php?a_code=A-10-1-2\&.

Akib, M., Abdurrahman, A. and Hamid, M. (2018) 'Students' Perception Toward English Teachers' Academic Performance in the Clasroom At Smp Muhammadiyah Al-Amin Sorong', Qalam : Jurnal Ilmu Kependidikan, 5(1), p. 52. doi: 10.33506/jq.v5i1.246.

Asrobi, M. and Amni, K. (2017) 'The Use of Dictogloss in Teaching Listening Comprehension for EFL Learners', Voices of English Language Education Society, 1(1), pp. 61-70. doi: 10.29408/veles.v1i1.394.

Dista, D. M. (2017) 'USING DICTOGLOSS TO IMPROVE LISTENING COMPREHENSION', ENGLISH EDUCATION JOURNAL (EEJ), 8(2), 149-163, (1985), pp. 149-163.

Feyten, C. M. (1991) 'The Power of Listening Ability: An Overlooked Dimension in Language Acquisition', The Modern Language Journal. WileyNational Federation of Modern Language Teachers Associations, 75(2), p. 173. doi: 10.2307/328825.

Gilakjani, A. P. and Ahmadi, M. R. (2011) 'A Study of Factors Affecting EFL Learners' English Listening Comprehension and the Strategies for Improvement', Journal of Language Teaching and Research, 2(5). doi: 10.4304/jltr.2.5.977-988.

Gilakjani, A. P. and Sabouri, N. B. (2016) 'Learners' Listening Comprehension Difficulties in English Language Learning: A Literature Review', English Language Teaching, 9(6), p. 123. doi: 10.5539/elt.v9n6p123.

Rahmi, R. (Regina) (2016) 'The Effectiveness of Dictogloss Technique in Teaching Listening at SMPN 2 Mesjid Raya', Getsempena English Education Journal. STKIP Bina Bangsa Getsempena Banda Aceh, 3(2), p. 217610.

Ruth Wajnryb (1990) Grammar Dictation - Ruth Wajnryb, Alan Maley - Google Buku, Oxford: Oxford University Press.

Vasiljevic, Z. (2010) 'Dictogloss as an Interactive Method of Teaching Listening Comprehension to L2 Learners', pp. 41-52. 